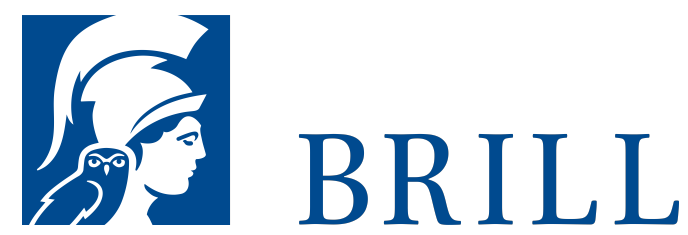

\title{
Orality and Literacy in the Demotic Tales
}

Author:Jacqueline E. Jay

In Orality and Literacy in the Demotic Tales, Jacqueline E. Jay extrapolates from the surviving ancient Egyptian written record hints of the oral tradition that must have run alongside it. The monograph's main focus is the intersection of orality and literacy in the extremely rich corpus of Demotic narrative literature surviving from the Greco-Roman Period. The many texts discussed include the tales of the Inaros and Setna Cycles, the Myth of the Sun's Eye, and the Dream of Nectanebo. Jacqueline Jay examines these Demotic tales not only in conjunction with earlier Egyptian literature, but also with the worldwide tradition of orally composed and performed discourse.

\section{Readership}

Egyptologists, particularly those interested in language and literature and Demotic studies, as well as those interested in Oral Tradition Studies and Comparative Literature.

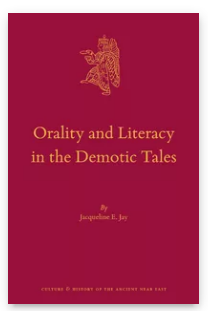

Pages: $\mathrm{x}, 363 \mathrm{pp}$.

Language:

English

Subjects:

Egyptology,

Ancient Near

East and Egypt,

Authors, Texts,

Literature,

Ancient Near

East and Egypt

Publisher: Brill

Series:

Culture and

History of the

Ancient Near

East, Volume: 81

E-Book (PDF)

Released online:

10 Jun 2016

ISBN: 978-90-

04-32307-O

List price

USD $\$ 192.00$

Hardback

Publication date:

23 Jun 2016

ISBN: 978-90-

O4-323o6-3

List price

USD \$192.00 
Jacqueline E. Jay, Ph.D. (2008, University of Chicago), is Associate Professor of History at Eastern Kentucky University. In addition to her work on ancient Egyptian literature, her current research projects focus on the publication of Demotic ostraca and graffiti.

For more information see brill.com

Order information: Order online at brill.com +44330333 0049 | customerservices@brill.com Submission information: brill.com/authors

Titles published by Brill | Fink, Brill | mentis or Brill | Schöningh: +49(o)71 5413279216 | brill@brocom.de 